\title{
Intracellular IL-4 and IFN- $\gamma$ expression in iNKT cells from patients with chronic lymphocytic leukemia
}

\author{
AGNIESZKA BOJARSKA-JUNAK ${ }^{1}$, MAŁGORZATA WALDOWSKA ${ }^{1}$, JUSTYNA WOŚ ${ }^{1}$, SYLWIA CHOCHOLSKA $^{2}$, \\ IWONA HUS ${ }^{3}$, WALDEMAR TOMCZAK ${ }^{2}$, MICHAŁ DZIK $^{1}$, MAREK HUS $^{2}$ and JACEK ROLIŃSKI ${ }^{1}$ \\ Departments of ${ }^{1}$ Clinical Immunology, ${ }^{2}$ Haematooncology and Bone Marrow Transplantation \\ and ${ }^{3}$ Clinical Transplantology, Medical University of Lublin, 20-093 Lublin, Poland
}

Received March 24, 2016; Accepted June 23, 2017

DOI: $10.3892 / \mathrm{ol} .2017 .7484$

\begin{abstract}
Malignant B cells in chronic lymphocytic leukemia serve an essential role in the whole immune response, so their interactions with other immune cells are more complex than observed in solid tumors. The latest study results indicate that the immune dysregulation in chronic lymphocytic leukemia (CLL) also affects a small population of invariant natural killer $\mathrm{T}$ cells (iNKT). Using peripheral blood iNKT cells obtained from patients with CLL, the objective of the present study was to assess the intracellular expression of typical cytokines involved in the Th1 (IFN- $\gamma$ ) and Th2 (IL-4) response pathways following stimulation with the iNKT-specific ligand $\alpha$-galactosylceramide. iNKT cells from patients with CLL exhibited upregulated IL-4 and IFN- $\gamma$ expression in comparison to those from HVs. No significant association between the ability of iNKT cells to produce IL- 4 or IFN- $\gamma$ and the expression of CDId on leukemic B lymphocytes or monocytes was identified. However, the function of iNKT cells was compromised in patients with CLL by a strong Th 2 bias (high IL-4 and low IFN- $\gamma$ expression). The ratio of $\mathrm{iNKT}^{+} \mathrm{IFN}-\gamma^{+}:$iNKT ${ }^{+} \mathrm{IL}-4^{+}$was significantly decreased in the CLL group when compared with HVs, and this decreased further as the disease progressed. This change may result in the promotion of leukemic B lymphocyte survival. Therefore, in the pathogenesis of CLL, Th2 bias may delay the antitumor response that relies on stimulation of the Th1 immune response.
\end{abstract}

\section{Introduction}

In chronic lymphocytic leukemia (CLL), malignant B lymphocytes, similar to other tumor cells, are in constant cooperation with the tumor microenvironment, which is formed by cancer cells through the recruitment and alteration of non-malignant cells of the immune system (1). In their proximate surroundings,

Correspondence to: Professor Agnieszka Bojarska-Junak, Department of Clinical Immunology, Medical University of Lublin, Chodźki 4a, 20-093 Lublin, Poland

E-mail: abojarskajunak@gmail.com

Key words: chronic lymphocytic leukemia, invariant natural killer $\mathrm{T}$ cells, interleukin- 4 , interferon- $\gamma, \mathrm{CD} 1 \mathrm{~d}$ neoplastic B cells interact with neighboring cells that include mesenchymal stromal cells, monocytes, monocyte-derived nurse-like cells, and T cells (2). These interactions provide B cell clones with supporting factors that inhibit or delay programmed apoptosis and thereby sustain disease progression (3). The dialogue between CLL B cells and interacting T lymphocytes may involve cytokines (4). The present study focused on a population of T lymphocytes, known as invariant natural killer $\mathrm{T}$ cells (iNKT) (5). The role of iNKT in tumor immunity is only partially understood and is poorly described in CLL. This unique cell subset combines features of T lymphocytes and NK cells (6). Unlike conventional T lymphocytes, they express markedly less variable $\mathrm{T}$ cell receptors (TCR $\alpha \beta)$, and are formed by an invariant $\alpha$ chain (V $\alpha 24 \mathrm{~J} \alpha 18)$ combined with a limited set of $\beta$ chains, mainly containing V $\beta 11$ (7-9). Using such TCR receptors, iNKT cells recognize lipids and glycolipids, presented by a non-classical MHC molecule known as CD1d (10). The agent most efficient in binding to CD1d is a synthetic compound that originated from marine sponges, known as $\alpha$-galactosylceramide ( $\alpha$-GalCer). The discovery of this potent agonist facilitated further understanding of the biology of iNKT (11-13). Activated iNKT cells simultaneously secrete interferon (IFN) $-\gamma$ and interleukin (IL)-4 (14). In addition, they can release other pro-inflammatory Th1 cytokines [such as tumor necrosis factor (TNF)- $\alpha$ and IL-6] and anti-inflammatory Th2 cytokines [such as IL-10, IL-13 and transforming growth factor (TGF)- $\beta$ ] (14-16). This enables iNKT cells to influence other cells of the immune system, including NK cells, cytotoxic T lymphocytes, helper T cells, B cells and antigen presenting cells (APC) (17-19). Certain pathological conditions may cause a change in the Th0-like pattern of cytokines secreted by iNKT cells and polarize their response in the Th1 or Th2 direction $(10,20)$. Such iNKT cells can modify the microenvironment and influence tumor control (21). The role of these cells in the pathogenesis and clinical course of CLL is not well known. Understanding the function of iNKT cells in this specific type of leukemia requires critical analysis of the cytokine release profile. In the current study, the intracellular expression of IFN- $\gamma$ and IL-4 was analyzed by stimulating the iNKT cells.

\section{Materials and methods}

Patients and samples. Peripheral blood (PB) samples were obtained from 60 patients with CLL (29 females and 31 males; 
median age, 67 years; range, 46-87 years) who met the diagnostic criteria of the International Workshop on Chronic Lymphocytic Leukemia (IWCLL) 2008 (22). All samples were collected at the time of diagnosis and prior to any anticancer therapy from September 2014 to June 2016 in the Department of Hemato-Oncology and Bone Marrow Transplantation of the Medical University of Lublin (Lublin, Poland). According to the Rai classification (23), 24 patients were Stage 0, 17 patients were Stage I, 7 patients were Stage II, 8 patients were Stage III and 4 patients were Stage IV. Participants' characteristics at the time of diagnosis are summarized in Table I. Control PB samples were obtained from 28 healthy volunteers (HVs; 12 females and 16 males, aged from 36-83 years, median, 57 years).

Ethics statement. The current study was approved by the Ethics Committee of the Medical University of Lublin (Lublin, Poland). Written informed consent was obtained from all patients with respect to the use of their blood for scientific purposes.

Activation of iNKT cells with $\alpha$-GalCer and analysis of intracellular $I L-4$ and IFN- $\gamma$ expression. PB samples were collected into heparinized tubes. PB samples were kept at room temperature and used within 1-2 h. Whole blood samples were cultured in round-bottom FACS tubes. For intracellular cytokine expression, iNKT cells in the PB were activated using $100 \mathrm{ng} / \mathrm{ml} \alpha$-GalCer (KRN700; Enzo Life Sciences, Inc., Farmingdale, NY, USA) for $24 \mathrm{~h}$ at $37^{\circ} \mathrm{C}$ in a $5 \% \mathrm{CO}_{2}$ atmosphere, followed by the addition of the protein transport inhibitor BD GolgiPlug ${ }^{\mathrm{TM}}$ (BD Biosciences, Franklin Lakes, NJ, USA) for the last $6 \mathrm{~h}$ of activation. Furthermore, this procedure was performed on non-activated lymphocytes using only BD GolgiPlug ${ }^{\mathrm{TM}}$ to assess the level of residual IL-4 and IFN- $\gamma$ synthesis from in vivo activation. Cultured cells were then stained with monoclonal antibodies (MoAbs) against cell-surface markers: anti-iNKT cells FITC (TCR Va24-J 18 , clone 6B11; cat. no. 558371, $20 \mu \mathrm{l} /$ test) and anti-CD3 PE-Cy5 (clone HIT3a; cat. no. 555341, $20 \mu \mathrm{l} /$ test) supplied by BD Biosciences; incubation was performed for $20 \mathrm{~min}$ at room temperature. Following membrane staining, cells were fixed and permeabilized with Cytofix/Cytoperm ${ }^{\mathrm{TM}}$ solution and Perm/Wash buffer (BD Biosciences), according to the manufacturer's protocol. Cells were then intracellularly stained with anti-IL-4 PE (clone 3010.211; BD Biosciences; cat. no. 340451, $20 \mu \mathrm{l} /$ test, $1.25 \mu \mathrm{g} / \mathrm{ml}$ ) or anti-IFN- $\gamma$ PE (clone 25723.11, BD Biosciences; cat. no. 340452, $20 \mu \mathrm{l} /$ test, $7.5 \mu \mathrm{g} / \mathrm{ml}$ ) MoAbs (30 min at $4^{\circ} \mathrm{C}$ in the dark) and washed twice in PBS. Finally, the cells were analyzed by flow cytometry using FACSCalibur ${ }^{\mathrm{TM}}$ (BD Biosciences).

Flow cytometry analysis. Samples were analyzed by flow cytometry directly following preparation. A FACSCalibur ${ }^{\mathrm{TM}}$ instrument (BD Biosciences) and BD CellQuest Pro software version 6.0 (BD Biosciences) were used. For each analysis, 200,000 events were acquired and analyzed. In the experiment, the percentage of iNKT cells with IL-4 or IFN- $\gamma$ expression was determined. iNKT were defined as V $\alpha 24-\mathrm{J} \alpha 18^{+} / \mathrm{CD}^{+}$ cells. Dot plots illustrating the analysis method for the identification of iNKT cells expressing IL-4 and IFN- $\gamma$ are presented in Fig. 1A-K. An acquisition gate was put on lymphocytes
Table I. Clinical characteristics of patients with CLL.

A, Total number of patients.

\begin{tabular}{|c|c|}
\hline Variables & Patient no. $(\%)$ \\
\hline \multicolumn{2}{|l|}{ Sex } \\
\hline Female (\%) & $29(48.30)$ \\
\hline Male (\%) & $31(51.70)$ \\
\hline \multicolumn{2}{|l|}{ Rai stage } \\
\hline $0(\%)$ & $24(40.00)$ \\
\hline $\mathrm{I}(\%)$ & $17(28.30)$ \\
\hline II $(\%)$ & $7(11.70)$ \\
\hline III (\%) & $8(13.30)$ \\
\hline IV $(\%)$ & $4(6.70)$ \\
\hline \multicolumn{2}{|l|}{ ZAP-70 (cut-off 20\%) } \\
\hline Positive $(\%)$ & $28(46.70)$ \\
\hline Negative (\%) & $32(53.30)$ \\
\hline \multicolumn{2}{|l|}{ CD38 (cut-off 20\%) ${ }^{\mathrm{b}}$} \\
\hline Positive $(\%)$ & $26(46.30)$ \\
\hline Negative (\%) & $34(56.70)$ \\
\hline \multicolumn{2}{|l|}{ Cytogenetic abnormalities } \\
\hline $\operatorname{del}(17 \mathrm{p} 13.1)(\%)$ & $4(6.70)$ \\
\hline $\operatorname{del}(11 q 22.3)(\%)$ & $6(10.00)$ \\
\hline $\begin{array}{l}\text { Without del(17p13.1) and } \\
\operatorname{del}(11 \mathrm{q} 22.3)(\%)\end{array}$ & $50(83.30)$ \\
\hline Patients requiring therapy & $12(20.00)$ \\
\hline Untreated patients & $48(80.00)$ \\
\hline
\end{tabular}

$\mathrm{B}$, Median range of patient data.

\begin{tabular}{lc}
\hline Variables & Median (range) \\
\hline Age at diagnosis (years) & $67(46-87)$ \\
WBC count $(\mathrm{G} / \mathrm{l})$ & $26.41(11.96-280.46)$ \\
Lymphocyte count (G/l) & $19.91(5.62-269.13)$ \\
$\beta 2 \mathrm{M}(\mathrm{mg} / \mathrm{dl})$ & $2.26(1.36-8.10)$ \\
$\mathrm{LDH}(\mathrm{IU} / \mathrm{l})$ & $387.00(287.00-839.00)$ \\
Hemoglobin $(\mathrm{g} / \mathrm{dl})$ & $14.20(8.20-17.20)$ \\
Platelets $(\mathrm{G} / \mathrm{l})$ & $183.00(70.00-339.00)$ \\
$\% \mathrm{CD} 19^{+} / \mathrm{CD} 5^{+} / \mathrm{ZAP}-70^{+}$cells $^{\mathrm{a}}$ & $17.02(2.41-58.43)$ \\
$\% \mathrm{CD} 19^{+} / \mathrm{CD} 5^{+} / \mathrm{CD} 38^{+}$cells $^{\mathrm{b}}$ & $10.13(0.72-87.72)$ \\
$\%$ iNKT cells $\left(\mathrm{V} \alpha 24-\mathrm{J} 18^{+} / \mathrm{CD}^{+}\right)^{\mathrm{c}}$ & $0.21(0.01-1.51)$
\end{tabular}

CLL, chronic lymphocytic leukemia; WBC, white blood cell; $\mathrm{LDH}$, Lactate dehydrogenase; $\beta 2 \mathrm{M}, \beta 2$-microglobulin. ${ }^{\text {aPatients }}$ with ZAP-70 expression lower or higher than $20 \%$ were classified

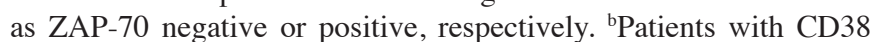
expression lower or higher than $30 \%$ were classified as CD38 negative or positive, respectively. ${ }^{\mathrm{c}} \%$ among $\mathrm{CD} 3^{+}$lymphocytes.

according to the forward scatter (FSC) and side scatter (SSC) properties (Fig. 1A). iNKT cells were defined and gated on a dot plot of iNKT FITC (TCR Va24-Ja18) vs. CD3 PE-Cy5 (Fig. 1B). Within those cells, the cytokine expressing cells 
A
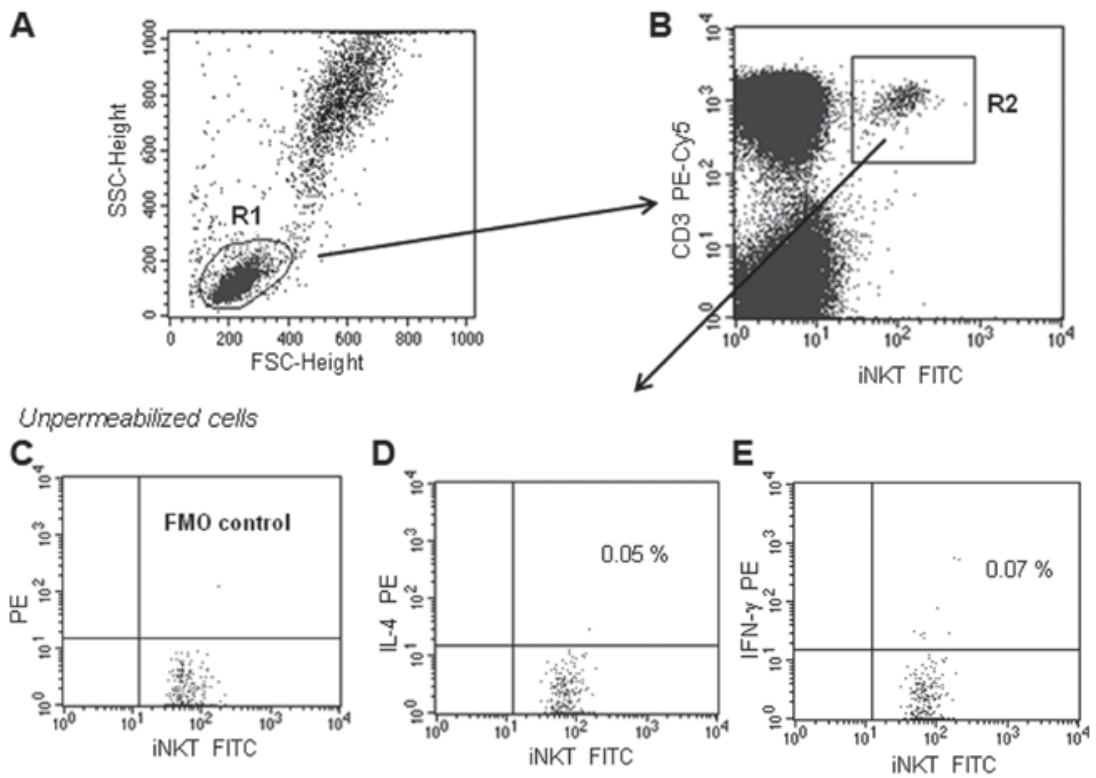

Permeabilized cells
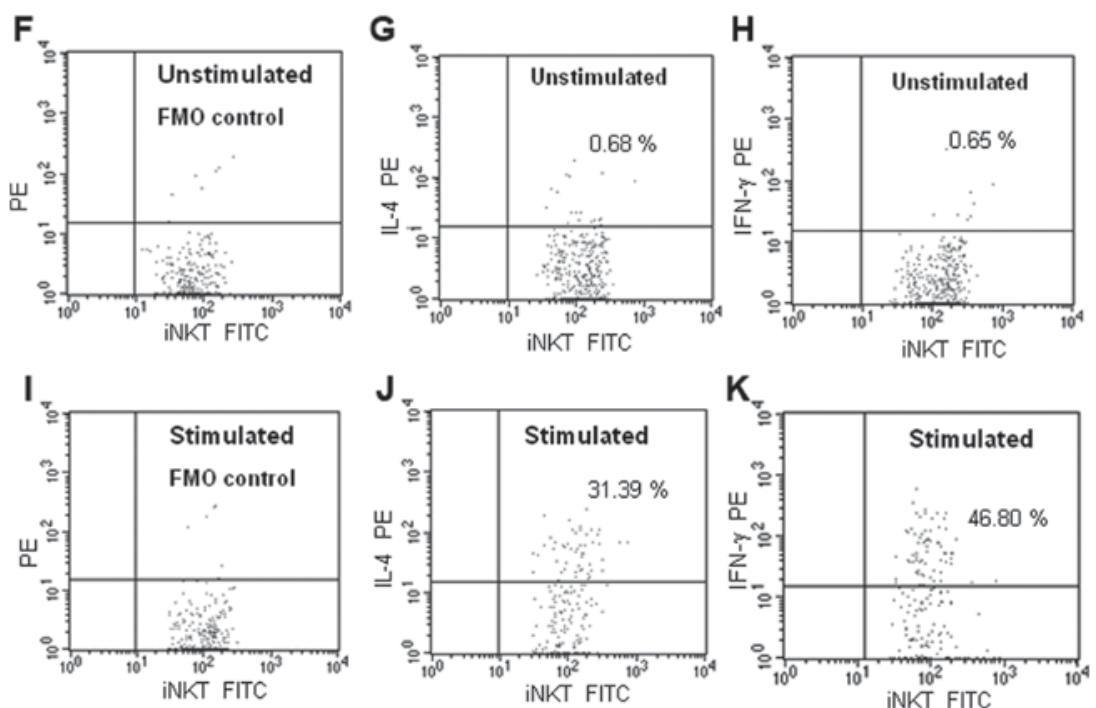

Figure 1. Representative dot plots illustrating the analysis method for the identification of iNKT ${ }^{+}$cells with IL-4 or IFN- $\gamma$ expression. (A) An acquisition gate was established based on FSC and SSC that included mononuclear cells. The R1 region was drawn around the lymphocytes. (B) The R1 gated events were analyzed for TCR Va24-Ja18 FITC (anti-iNKT) and CD3 PE-Cy5 staining, and the positive cells were gated (region R2). The dot plots C-K were established by the combined gating of events using R1 and R2 regions. Three dot plots (C-E) indicate no-permeabilization control (checking whether the antibody binds to the antigen only after permeabilization). Six dot plots (F-K) indicate the identification of iNKT cells with intracellular IL-4 or IFN- $\gamma$ (after permeabilization). (C, F and I) Dot plots indicating the FMO control, which contains all the fluorochromes in a panel, except for the one (IL-4 PE or IFN- $\gamma$ PE) that was measured The final dot plots indicate iNKT cells (TCR V $\alpha 24-J \alpha 18$ FITC $^{+}$CD3PE-Cy5 $5^{+}$cells positive for (D, G and J) IL-4 or (E, H and K) IFN- $\gamma$. (D and E) The number in the upper right quadrant represents the percentage of iNKT cells that bound the anti-IL-4 or anti-IFN- $\gamma$ MoAbs without permeabilization (non-specific binding). ( $\mathrm{G}$ and $\mathrm{H}$ ) The two dot-plots represent IL-4 and IFN- $\gamma$ expression in the unstimulated iNKT cells (non-activated cells from 24-h culture only with BD GolgiPlug ${ }^{\mathrm{TM}}$ ). ( $\mathrm{J}$ and $\mathrm{K}$ ) The number in the upper right quadrant represents the percentage of iNKT cells with intracellular IL-4 or IFN- $\gamma$ expression (after $\alpha$-GalCer stimulation). FSC, forward scatter; SCC side scatter; FMO, Fluorescence Minus One Control; CLL, chronic lymphocytic leukemia; iNKT, invariant natural killer T cells; IL, interleukin; IFN, interferon; $\alpha$-GalCer, $\alpha$-galactosylceramide; MoAb, monoclonal antibody.

were identified. To establish the gating strategy, a fluorescence minus one (FMO) control was used. The FMO control tube included all antibodies that were used for iNKT cell staining (anti-TCR Va24-Ja18 FITC and anti-CD3 PE-Cy5), except for the antibody (IL-4 PE or IFN- $\gamma$ PE) that was measured. The FMO control allowed the consideration of any spread of fluorochromes into the unlabeled channel, and the placing of gates in the correct place. The results are expressed as the percentage of iNKT cells with intracellular IL-4 or IFN- $\gamma$ expression. Specificity of anti-IL-4 PE and anti-IFN- $\gamma$ PE
MoAbs was evaluated through the estimation of unpermeabilized cells (Fig. 1C-E). Staining of unstimulated (24-h culture only with BD GolgiPlug ${ }^{\text {TM }}$; Fig. 1F-H) as well as stimulated iNKT cells was performed (Fig. 1I-K).

Sorting of iNKT cells for reverse transcription-quantitative polymerase chain reaction (RT-qPCR). In 10 CLL cases and $5 \mathrm{HV}$ cases (from 24-h culture with and without $\alpha$-GalCer stimulation), the iNKT cells were purified. A BD FACSAria ${ }^{\mathrm{TM}}$ flow cytometer (BD Biosciences) was used for iNKT cell 
sorting. In this case, the iNKT cells were labeled with antibodies against TCR, V $224-\mathrm{J} \alpha 18$ PE and CD3 FITC (BD Biosciences), following which the double-positive population was selected. A standard whole-blood assay with erythrocyte cell lysis was used for preparing the PB specimens. After sorting, the iNKT cell purity was $>97 \%$.

RNA preparation and RT-qPCR) for IL-4 and IFN- $\gamma$ in iNKT cells. Purified iNKT cells were used for RNA isolation. Total RNA was isolated using the QIAamp ${ }^{\circledR}$ RNA Blood Mini kit (Qiagen, Inc., Valencia, CA, USA; cat. no. 52304). RNA was transcribed into cDNA using the QuantiTect ${ }^{\circledR}$ Reverse Transcription kit (Qiagen, Inc.; cat. no. 205311), according to the manufacturer's protocol. RT-qPCR was performed using TaqMan reagents specific for human IL-4 and IFN- $\gamma$ (Applied Biosystems; Thermo Fisher Scientific, Inc., Waltham, MA, USA; cat. no. 4331182), and $\beta$-actin was used as the internal control (Applied Biosystems; Thermo Fisher Scientific, Inc.; cat. no. $4326315 \mathrm{E})$. RT-qPCR reactions were run for 40 cycles using universal cycling conditions $\left(95^{\circ} \mathrm{C}\right.$ for $10 \mathrm{~min}$ followed by 40 cycles at $95^{\circ} \mathrm{C}$ for $15 \mathrm{sec}$ and $60^{\circ} \mathrm{C}$ for $1 \mathrm{~min}$ ) on an Applied Biosystems 7300 Real-Time PCR System. Data were normalized to $\beta$-actin expression (endogenous control), analyzed using the threshold cycle $(\mathrm{Cq})$ and presented as $2^{\Delta \mathrm{Cq}}$. $\Delta \mathrm{Cq}$ is the difference between the $\mathrm{Cq}$ of the target gene $\left(\mathrm{Cq}_{t}\right)$ and the reference gene $\left(\mathrm{Cq}_{\mathrm{r}} ; \mathrm{DCq}=\mathrm{Cq}_{\mathrm{t}}-\mathrm{Cq}_{\mathrm{r}}\right)(24)$.

Analysis of CDld expression on monocytes and B cells. Flow cytometry analysis of $\mathrm{CD} 19^{+} \mathrm{B}$ cells and $\mathrm{CD} 14^{+}$monocytes expressing CD1d was performed on fresh PB samples stained with anti-CD1d PE (clone CD1d42; cat. no. 550255, $20 \mu \mathrm{l} /$ test), anti-CD19 FITC (clone SJ25C1; cat. no. 34040, $20 \mu 1 /$ test, $6 \mu \mathrm{g} / \mathrm{ml}$ ) and anti-CD14 FITC (clone MфP9; cat. no. 347493; $20 \mu \mathrm{l} /$ test, $25 \mu \mathrm{g} / \mathrm{ml}$ ) MoAbs from BD Biosciences. Cells were incubated for $20 \mathrm{~min}$ at room temperature. A standard whole-blood assay with erythrocyte cell lysis was used for preparing all PB specimens. Samples were analyzed by flow cytometry directly following preparation. In the experiment, the percentage of $\mathrm{CD}_{1 \mathrm{~d}} / \mathrm{CD} 19^{+}$and $\mathrm{CD} 1 \mathrm{~d}^{+} / \mathrm{CD} 14^{+}$cells, and the level of CD1d expression on monocytes and B cells, indicated by the mean fluorescence intensity (MFI), were analyzed. Dot plots illustrating the analysis method for the identification of monocytes with membrane expression of CD1d are presented in Fig. 2. The identification method of CD1d-positive CD19+ B lymphocytes was exhibited in our previous study (25).

Cells isolation for the determination of apoptosis. Mononuclear cells were separated from PB samples by density gradient centrifugation with Biocoll Separating Solution (Biochrom, Ltd., Cambridge, UK) for $25 \mathrm{~min}$ at $400 \mathrm{x}$ g and room temperature. Interphase cells were removed, washed twice and resuspended in PBS.

Determination of apoptosis by MitoTracker ${ }^{\circledR}$ Red CMXRos. In 20 patients with CLL an apoptosis analysis within the CD19 ${ }^{+}$ cell population was performed. A previously described method was used for flow cytometric examination of the percentage of early apoptotic cells $\left(\Delta \Psi \mathrm{m}^{\text {low }}\right)(26-28)$. The level of apoptosis was measured by chloromethyl-X-rosamine staining (MitoTracker ${ }^{\circledR}$ Red CMXRos; Molecular Probes; Thermo
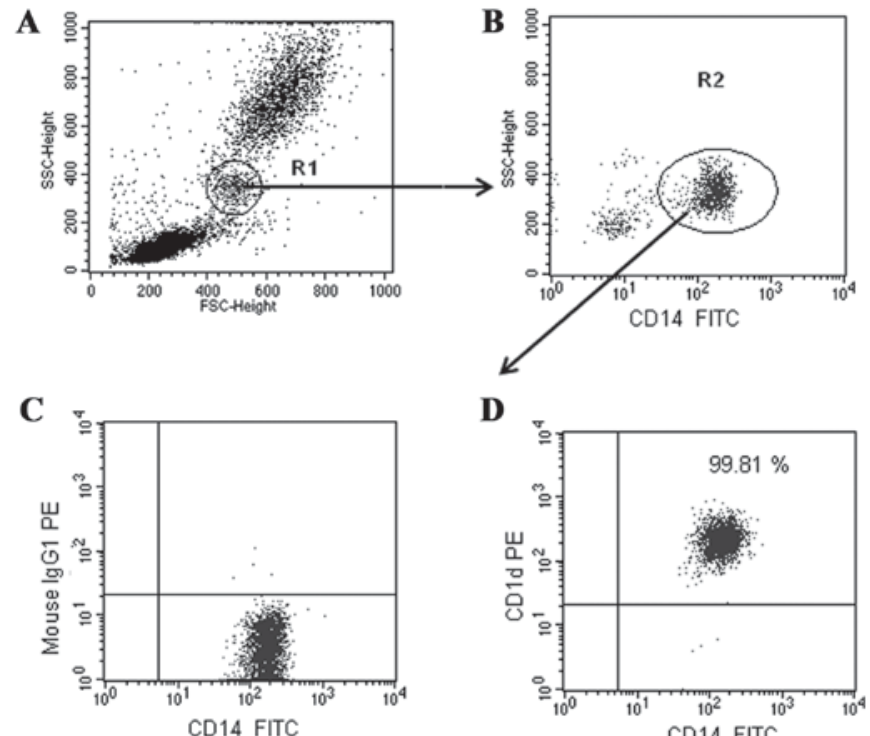

D

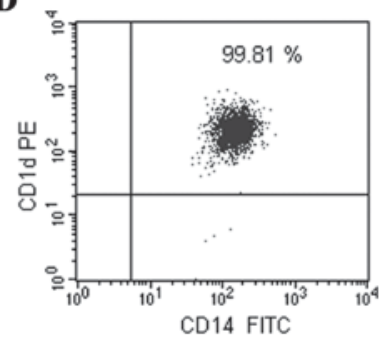

$\mathbf{E}$
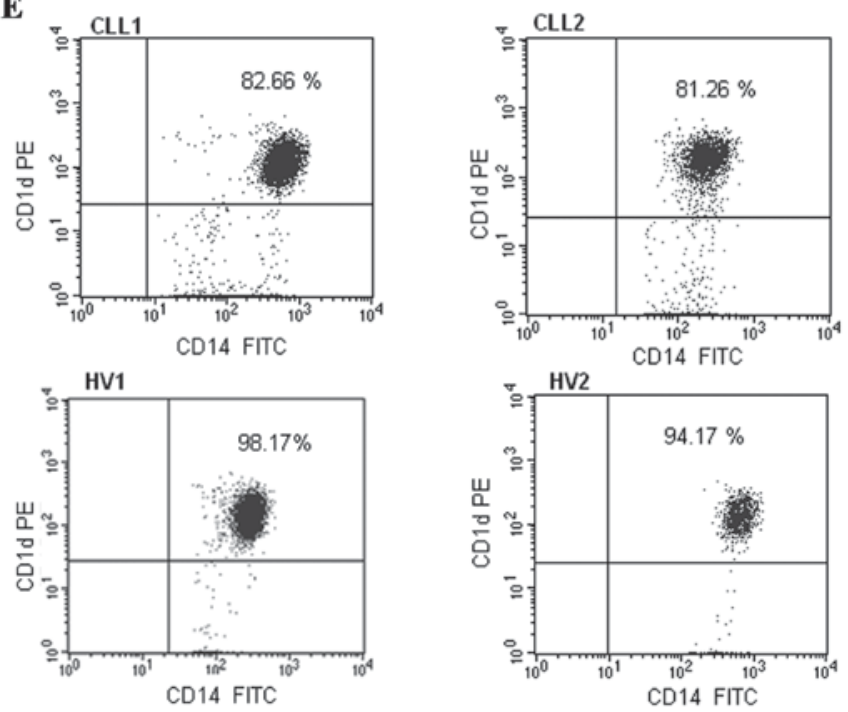

Figure 2. Representative dot plots illustrating the method of analysis for the identification of monocytes with CD1d expression. (A) First, monocytes were gated (R1 region) based on FSC and SSC. (B) Dot plot of monocytes: CD14 FITC vs. SSC. CD14 positive cells were selected (region R2). Final dot plots (C) CD14 FITC vs. mouse IgG1 PE and (D and E) CD14 FITC vs. CD1d PE were established via the combined gating of events using R1 and R2 regions. The numbers in the upper right quadrant on the dot plots represent the percentage of monocytes with CD1d membrane expression $\left(\mathrm{CD} 14^{+} \mathrm{CD} 1 \mathrm{~d}^{+}\right)$ (E) The dot plots indicate two representative types of CD1d expression on the monocytes from patients with CLL (CLL1-CLL2) and two representative types of CD1d expression on the monocytes from HVs (HV1-HV2). FSC, forward scatter; SCC side scatter; HV, healthy volunteer.

Fisher Scientific, Inc.; cat. no. M7512). CMXRos is a cationic lipophilic fluorochrome that can be used to detect disruptions in the mitochondrial membrane potential $(\Delta \Psi \mathrm{m})$. CMXRos was used in combination with an anti-CD19 FITC MoAb (BD Biosciences). Mononuclear cells were incubated with CMXRos for $30 \mathrm{~min}$ at $37^{\circ} \mathrm{C}$ and, after $15 \mathrm{~min}$ of incubation, the anti-CD19 MoAb was added. The $\mathrm{CD} 19^{+}$cells that were determined to be apoptotic exhibited a decrease in the mitochondrial membrane potential following CMXRos staining $\left(\Delta \Psi \mathrm{m}^{\text {low }}\right)$. The percentage of apoptotic cells $\left(\Delta \Psi \mathrm{m}^{\text {low }} / \mathrm{CD} 19^{+}\right)$ was measured at the time of diagnosis (ex vivo), and in vitro 
A
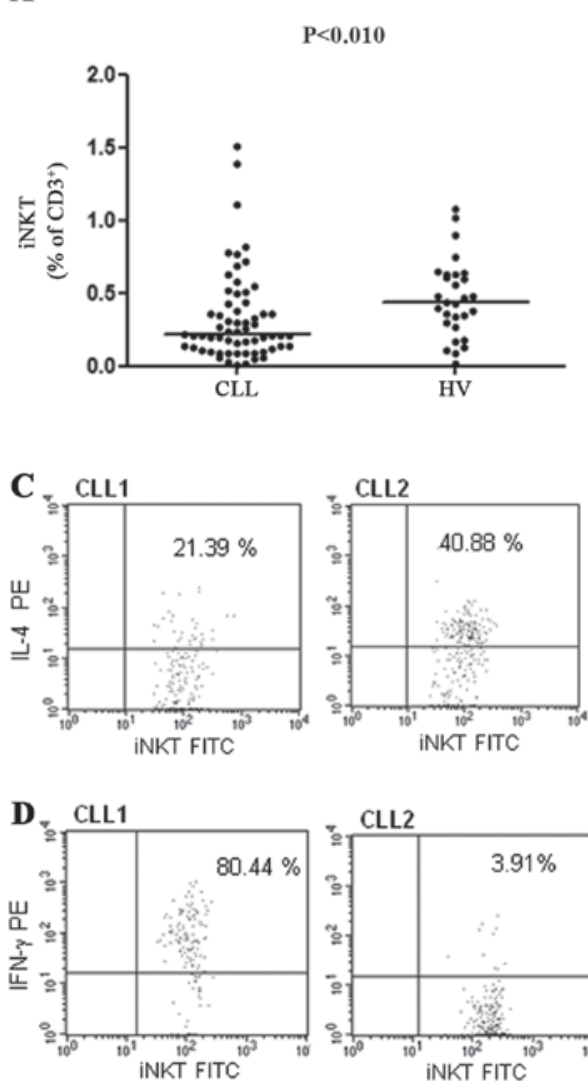

B
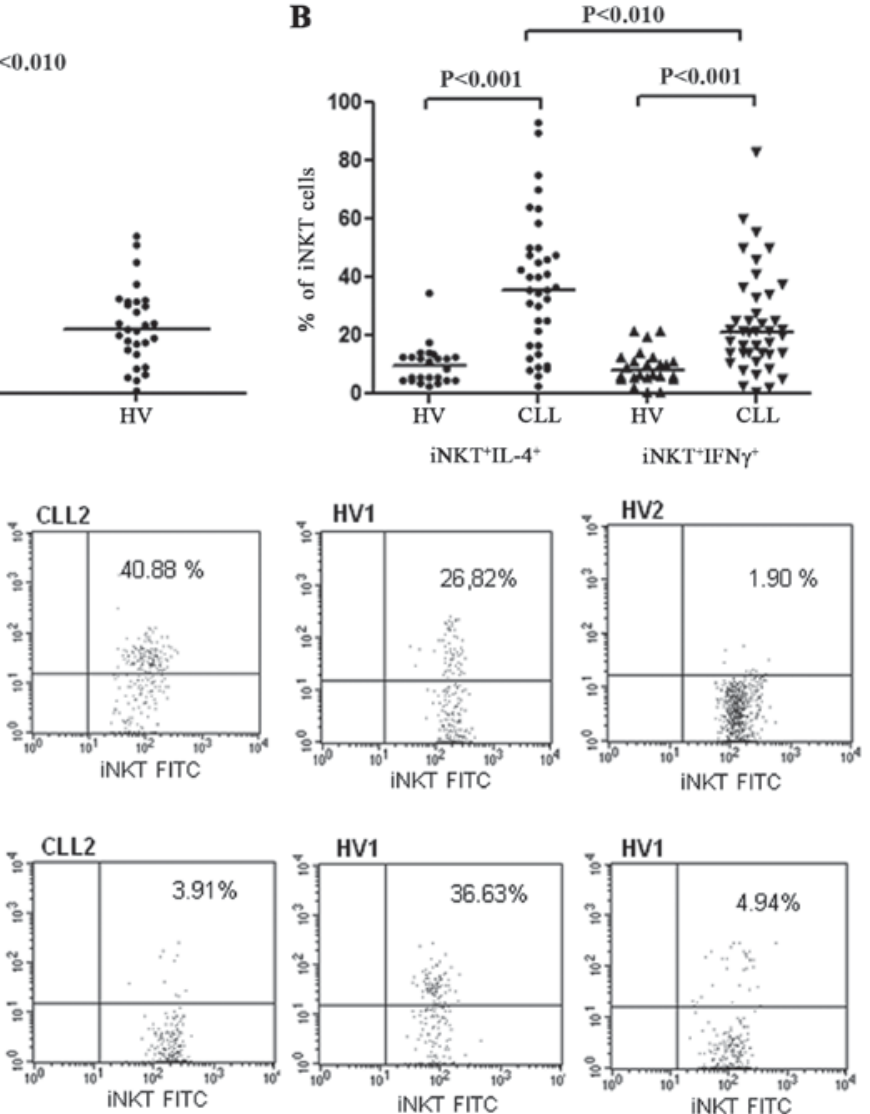

Figure 3. (A) Percentage of CLL iNKT cells (among CD3 ${ }^{+} \mathrm{T}$ lymphocytes) in patients with CLL and in HVs. (B) Percentage of CLL iNKT cells with IL-4 or IFN- $\gamma$ expression in patients with CLL and in HVs. (C) Dot plots depict iNKT cells with high and low expression of IL-4 for two patients with CLL (CLL1, CLL2) and two HVs (HV1, HV2). (D) Dot plots depict iNKT cells with high and low expression of IFN- $\gamma$ for two patients with CLL (CLL1, CLL2) and two HVs (HV1, HV2). CLL, chronic lymphocytic leukemia; iNKT, invariant natural killer T cells; IL, interleukin; IFN, interferon; HV, healthy volunteer.

after $24 \mathrm{~h}$ incubation at $37^{\circ} \mathrm{C}$ in RPMI-1640 supplemented with $2 \mathrm{mmol} / \mathrm{l} \mathrm{L-glutamine} \mathrm{(Biochrom,} \mathrm{Ltd.,} \mathrm{Cambridge,}$ UK; cat. no. FG1215), 10\% fetal calf serum (Biochrom, Ltd.; cat. no. S0113), $100 \mathrm{U} / \mathrm{ml}$ penicillin and $100 \mu \mathrm{g} / \mathrm{ml}$ streptomycin (Biochrom, Ltd.; cat. no. A2212), and with and without $100 \mathrm{ng} / \mathrm{ml} \alpha$-GalCer stimulation.

Analysis of CD69 expression on iNKT cells. For the assessment of CD69 expression on iNKT cells, PB mononuclear cells were incubated with the following MoAbs: TCR Va24-Ja18 FITC (clone 6B11; BD Biosciences; cat. no. 558371; 20 m/test), CD3 PE-Cy5 (clone HIT3a; BD Biosciences; cat. no. 555341; $20 \mu 1 /$ test) and CD69 PE (clone FN50; BD Biosciences; cat. no. 555531, $20 \mu \mathrm{l} /$ test). Samples were analyzed using flow cytometry immediately following preparation.

Statistical analysis. Data are presented as the median and range. The Mann-Whitney $U$ test was applied for statistical comparisons between the CLL and HV groups, as well as between the patient subgroups. The Spearman's rank correlation coefficient was used for correlation analysis. Statistica version 9.0 PL software (StatSoft, Cracow, Poland) and GraphPad Prism software version 5.0 (GraphPad Software, Inc., La Jolla, CA, USA) were used for statistical procedures. $\mathrm{P}<0.05$ was considered to indicate a statistically significant difference.

\section{Results}

Intracellular IL-4 and IFN- $\gamma$ expression in iNKT cells. The percentage of iNKT cells within $\mathrm{CD}^{+} \mathrm{T}$ lymphocytes was significantly decreased in patients with CLL in comparison to the HVs (median, 0.21 vs. $0.42 \%, \mathrm{P}<0.01$; Fig. 3A). The frequency of iNKT cells also decreased with the disease stage. The median percentage of iNKT cells in stage 0 was 0.25 , $0.21 \%$ in stages I/II and $0.13 \%$ in stages III/IV, according to the Rai classification. However, the difference was not significant. In the group of patients with CLL no significant association was identified between the frequency of iNKT cells in the PB and the expression of ZAP-70 or CD38 (data not presented).

The function of iNKT lymphocytes was investigated through the analysis of intracellular cytokine expression following stimulation with the iNKT-specific ligand $\alpha$-GalCer. At the end of a 24-h stimulation period, the synthesis of IL-4 and IFN- $\gamma$ in iNKT cells was assessed by intracellular staining. In patients with CLL as well as in HVs, the percentage of iNKT cells with intracellular IL-4 or IFN- $\gamma$ expression in non-activation assays was frequently $<1 \%$, comparable with the level of auto-fluorescence (Fig. 1G-H). In vitro stimulation of iNKT cells with $\alpha$-GalCer resulted in CD69 upregulation, indicating the activation of iNKT cells (median of iNKT ${ }^{+} \mathrm{CD} 69^{+}$cells, $15.79 \%$ before and $29.32 \%$ after $\alpha$-GalCer). Higher percentages of iNKT with IL-4 expression were noted in patients with 


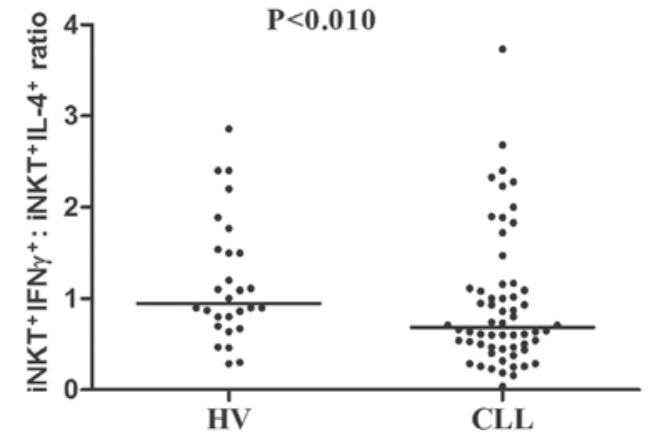

Figure 4. iNKT ${ }^{+} \mathrm{IFN}-\gamma^{+}$: iNKT ${ }^{+} \mathrm{IL}-4^{+}$ratio in HVs and in patients with CLL. CLL, chronic lymphocytic leukemia; iNKT, invariant natural killer T cells; IL, interleukin; IFN, interferon; HV, healthy volunteer.

CLL (median, 35.20\%), as compared with in the HV control group (median, 12.64\%; $\mathrm{P}<0.001$, Fig. 3B). There was also a statistically significant difference between patients with CLL and HVs in terms of the percentage of iNKT cells with IFN- $\gamma$ expression (median, $10.96 \%$ vs. $24.50 \%$; P<0.001; Fig. 3B). Representative plots of data from two patients with CLL and two HVs with distinct IL-4 and IFN- $\gamma$ expression profiles are presented in Fig. 3C-D. In patients with CLL, the percentage of iNKT $\mathrm{IL}^{+} 4^{+}$cells was significantly higher when compared with the percentage of iNKT IFN- $\gamma^{+}$cells $(\mathrm{P}<0.01$; Fig. 3B). Further analysis revealed that the ratio of iNKT ${ }^{+} \mathrm{IFN}-\gamma^{+}$to iNKT $\mathrm{IL}^{+} 4^{+}$ was significantly decreased in the CLL group compared with the HV group (median, 0.68 vs. 0.95 ; P<0.01; Fig. 4).

The CLL group was further divided into three risk groups: Low risk (stage 0), intermediate-risk (stage I or II), and high-risk (stage III or IV). Each of these groups exhibited a significantly higher percentage of iNKT $\mathrm{IL}^{+} 4^{+}$cells in comparison with the HVs. However, there was no significant difference between the three risk groups (Fig. 5A). Furthermore, each risk group exhibited a significantly higher percentage of iNKT ${ }^{+}$IFN $-\gamma^{+}$ cells in comparison with the control group (Fig. 5B). However, when the risk groups were compared, the only significant finding was that patients with CLL at Rai stage III-IV had a lower percentage of iNKT ${ }^{+} \mathrm{IFN}-\gamma^{+}$(median, 19.65\%) compared with those at Rai stage 0 (median, 33.0\%; P<0.05; Fig. 5B). Additional analysis indicated that the ratio of iNKT ${ }^{+}$IFN $-\gamma^{+}$ to iNKT ${ }^{+} \mathrm{IL}_{-} 4^{+}$decreased during disease progression. The ratio was lower in patients at stages III-IV (median, 0.39) than at stages I-II (median, 0.66) or 0 (median, 0.86; Fig. 5C). Nevertheless, the difference was statistically significant only between the low and high-risk groups $(\mathrm{P}<0.05)$. Only the iNKT IFN- $\gamma^{+}$iNKT IL- $4^{+}$ratio of the intermediate-risk and high-risk groups was significantly lower in comparison with the HVs (Fig. 5C).

The proportions of CLL group iNKT differed slightly in the intracellular expression of cytokines, depending on the ZAP-70 factor expression. The percentage of iNKT cells expressing IL-4 was increased in ZAP-70-positive patients, as compared with in ZAP-70-negative patients (Table II). Additionally, a tendency towards an increased percentage of iNKT cells expressing IL-4 in CD38-positive in comparison with CD38-negative patients was noted, but this difference was not statistically significant (Table II). There was no significant difference in the iNKT ${ }^{+} \mathrm{IFN}-\gamma^{+}$percentage between the
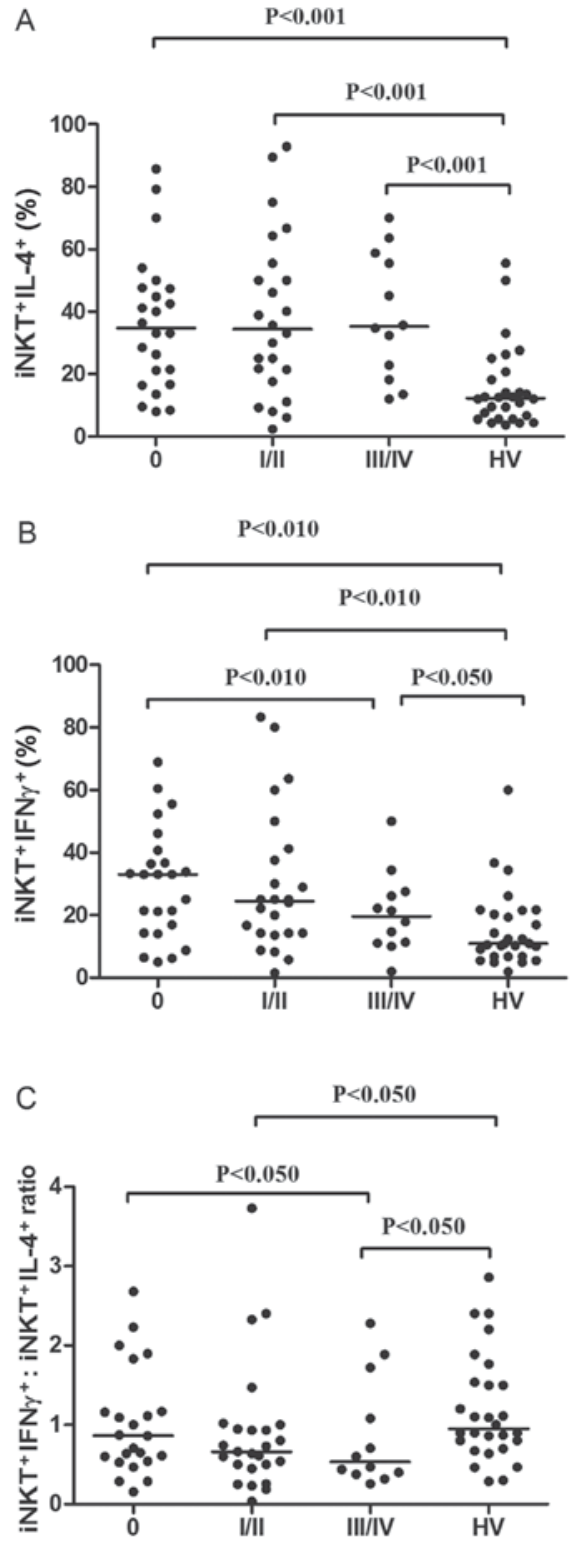

Figure 5. Percentage of CLL iNKT cells with (A) IL-4 or (B) IFN- $\gamma$ expression in patients with CLL at various disease stages (three risk groups), as compared with in HVs. (C) Inter-group comparisons of the iNKT IFN- $\gamma^{+}$: $\mathrm{iNKT}^{+} \mathrm{IL}-4^{+}$ratio among different risk groups of patients with CLL, and HVs. CLL, chronic lymphocytic leukemia; iNKT, invariant natural killer T cells; IL, interleukin; IFN, interferon; HV, healthy volunteer.

ZAP-70-positive and ZAP-70-negative or the CD38-positive and CD38-negative patients. However, there was a statistically significant difference in the iNKT ${ }^{+} \mathrm{IFN}-\gamma^{+:} \mathrm{iNKT}^{+} \mathrm{IL}_{-} 4^{+}$ ratio between ZAP-70-positive and ZAP-70-negative patients (Table II).

A higher percentage of iNKT ${ }^{+} \mathrm{IL}-4^{+}$cells and a lower percentage of iNKT $\mathrm{IFN}^{+} \boldsymbol{\gamma}^{+}$cells were observed in patients carrying unfavorable cytogenetic abnormalities (11q22.3 and/or 17p13.1 deletion), compared with in patients without these genetic changes (Table II). Similarly, patients with del (11q22.3) and/or del (17p13.1) exhibited a lower ratio of iNKT ${ }^{+} I F N-\gamma^{+}$to iNKT ${ }^{+} \mathrm{IL}^{-} 4^{+}$. However, these differences were not statistically significant (Table II).

The percentage of iNKT $\mathrm{IL}^{4} 4^{+}$cells correlated positively with the WBC count $(\mathrm{R}=0.387$; $\mathrm{P}<0.05)$, PB lymphocyte count 
Table II. Percentage of iNKT cells with expression of IL-4 or IFN- $\gamma$ divided according to adverse prognostic factors.

\begin{tabular}{lccc}
\hline Variable & ZAP-70-positive patients & ZAP-70-negative patients & P-value \\
\hline iNKT $^{+} I L-4+(\%)$ & $37.86(8.00-92.86)$ & $30.19(2.36-89.47)$ & $0.049^{\mathrm{a}}$ \\
$\mathrm{iNKT}^{+} \mathrm{IFN}_{-} \gamma^{+}(\%)$ & $22.23(2.00-68.97)$ & $25.00(0.60-83.33)$ & 0.495 \\
$\mathrm{iNKT}^{+} \mathrm{IFN}-\gamma^{+} / \mathrm{iNKT}^{+} \mathrm{IL}^{+} 4^{+}$ratio & $0.60(0.04-2.28)$ & $0.89(0.16-3.73)$ & $0.046^{\mathrm{a}}$
\end{tabular}

\begin{tabular}{|c|c|c|c|}
\hline & CD38-positive patients & CD38-negative patients & \\
\hline $\mathrm{iNKT}^{+} \mathrm{IL}-4^{+}(\%)$ & $36.71(8.00-92.86)$ & $33.85(2.36-89.47)$ & 0.462 \\
\hline $\mathrm{iNKT}^{+} \mathrm{IFN}-\gamma^{+}(\%)$ & $21.43(5.81-68.97)$ & $25.55(0.60-83.33)$ & 0.382 \\
\hline \multirow[t]{2}{*}{$\mathrm{iNKT}^{+} \mathrm{IFN}_{-} \gamma^{+} / \mathrm{iNKT}^{+} \mathrm{IL} 4^{+}$ratio } & $0.57(0.16-2.68)$ & $0.77(0.04-3.73)$ & 0.176 \\
\hline & $\operatorname{del}(17 \mathrm{p} 13.1)$ and/or del(11q22.3) & Without del(17p13.1), del(11q22.3) & \\
\hline $\mathrm{iNKT}^{+} \mathrm{IL}-4^{+}(\%)$ & $32.13(12.07-55.56)$ & $37.71(2.36-92.86)$ & 0.548 \\
\hline $\mathrm{iNKT}^{+} \mathrm{IFN}-\gamma^{+}(\%)$ & $16.08(10.53-60.62)$ & $24.00(0.60-83.33)$ & 0.064 \\
\hline $\mathrm{iNKT}^{+} \mathrm{IFN}_{-} \gamma^{+} / \mathrm{iNKT}^{+} \mathrm{IL}^{-} 4^{+}$ratio & $0.53(0.32-2.29)$ & $0.71(0.04-3.73)$ & 0.365 \\
\hline
\end{tabular}

The P-value was calculated using the Mann-Whitney U test. ${ }^{\mathrm{a}} \mathrm{P}<0.05$ was considered to indicate a statistically significant difference.

Table III. Percentage of iNKT cells with intracellular expression of IL-4 or IFN- $\gamma$ in untreated and requiring therapy patients with CLL.

\begin{tabular}{|c|c|c|c|c|c|c|}
\hline & \multicolumn{2}{|c|}{ NKT/IL-4\% } & \multicolumn{2}{|c|}{ NKT/IFN \% } & \multicolumn{2}{|c|}{ IFN:IL-4 } \\
\hline & $\begin{array}{l}\text { Untreated } \\
\text { patients }\end{array}$ & $\begin{array}{c}\text { Requiring } \\
\text { therapy }\end{array}$ & $\begin{array}{l}\text { Untreated } \\
\text { patients }\end{array}$ & $\begin{array}{l}\text { Requiring } \\
\text { therapy }\end{array}$ & $\begin{array}{c}\text { Untreated } \\
\text { patients }\end{array}$ & $\begin{array}{l}\text { Requiring } \\
\text { therapy }\end{array}$ \\
\hline Median & 34.36 & 35.20 & 24.50 & 23.61 & 0.71 & 0.53 \\
\hline Minimum & 2.36 & 12.07 & 0.60 & 11.11 & 0.04 & 0.32 \\
\hline Maximum & 92.86 & 58.82 & 83.33 & 60.00 & 3.73 & 2.40 \\
\hline
\end{tabular}

Table IV. Ex vivo and in vitro (with and without $\alpha$-GalCer stimulation) percentage of apoptotic CD19+ cells $\left(\Delta \Psi \mathrm{m}^{\text {low }} / \mathrm{CD} 19^{+}\right)$evaluated by CMXRos.

\begin{tabular}{lr}
\hline Conditions & $\begin{array}{c}\Delta \Psi \mathrm{m}^{\text {low }} / \mathrm{CD} 19^{+}(\%) \\
\text { Median (range) }\end{array}$ \\
\hline ex vivo & $3.60(0.40-26.70)$ \\
24-h in vitro culture without stimulation & $19.20(5.30-30.60)$ \\
24-h in vitro culture with $\alpha$-GalCer & $22.50(7.60-28.70)$ \\
\hline
\end{tabular}

$(\mathrm{R}=0.358 ; \mathrm{P}<0.05)$ and $\beta_{2}$-microglobulin levels $(\mathrm{R}=0.474$; $\mathrm{P}<0.01)$. There was also an inverse correlation between the iNKT ${ }^{+} I F N-\gamma^{+}$: iNKT ${ }^{+} I L-4{ }^{+}$ratio and the $\mathrm{WBC}$ count $(\mathrm{R}=-0.302 ; \mathrm{P}<0.05)$ and $\beta_{2}$-microglobulin levels $(\mathrm{R}=0.507$; $\mathrm{P}<0.01)$. However, no significant association between the percentage of iNKT ${ }^{+} \mathrm{IFN}-\gamma^{+}$cells and other disease parameters was identified.

In the present study, PB samples were obtained from untreated patients with CLL diagnosed between September 2014 and June 2016 (21 months of observations). During the follow-up period, the treatment was initiated in 12 patients $(20 \%)$. For these patients, the median time to treatment (TTT) was 7 months (range, 0-12 months). TTT was defined as the interval from the date of diagnosis to the date of first treatment. There was no significant association between the percentage of iNKT ${ }^{+} \mathrm{IL}_{-} 4^{+}$or $\mathrm{iNKT}{ }^{+} \mathrm{IFN}-\gamma^{+}$cells and the time to treatment. No statistically significant differences were identified in the percentage of iNKT ${ }^{+} \mathrm{IL}-4^{+}$and iNKT ${ }^{+} \mathrm{IFN}-\gamma^{+}$ or the iNKT ${ }^{+} \mathrm{IFN}-\gamma^{+}$: iNKT ${ }^{+} \mathrm{IL}-4^{+}$ratio between patients requiring therapy, as compared with patients without treatment, during the observation period (Table III).

Expression of IL-4 and IFN- $\gamma$ mRNAs in iNKT cells. Purified iNKT cells were analyzed for IL- 4 and IFN- $\gamma$ mRNA expression using RT-qPCR. For the analysis of IL-4 and IFN- $\gamma$ mRNA expression, each sample was normalized to $\beta$-actin. Generally, after $24 \mathrm{~h}$ of culture without stimulation, no IL-4 or IFN- $\gamma$ mRNA was identified in the iNKT cells from patients with CLL or from the HVs. Only in one patient (p\#5) was the presence of IL- 4 and IFN- $\gamma$ mRNA in an unstimulated culture observed (Fig. 6). iNKT cells from patients with CLL and HVs were identified to express IL-4 (median $2^{-\Delta \mathrm{Cq}}$ : 6.70 vs. 0.20 ) and 

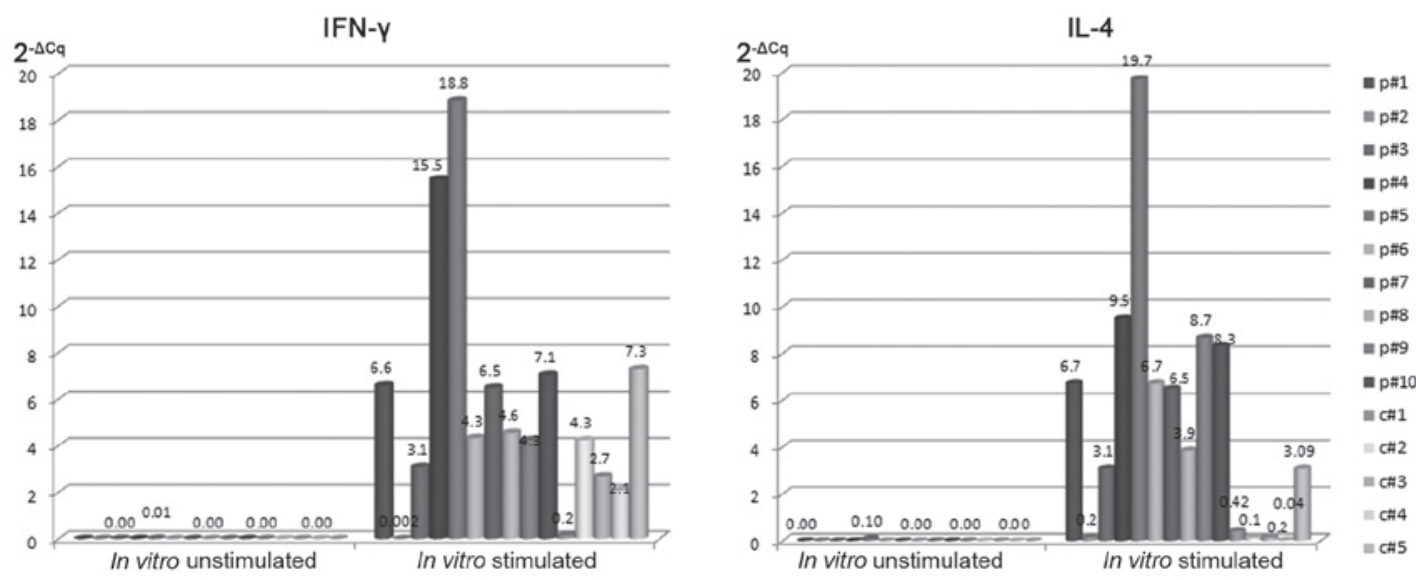

Figure 6. Quantitative expression of IL-4 and IFN- $\gamma$ mRNA. RT-qPCR was performed on RNA samples isolated from iNKT cells obtained from patients with CLL ( $\mathrm{p} \# 1$ to $\mathrm{p \# 10)}$ ) or from iNKT cells obtained from HVs (c\#1 to c\#5). IL-4 and IFN- $\gamma$ mRNA expression was analyzed in iNKT cells following a 24-h culture with or without $\alpha$-GalCer stimulation. CLL, chronic lymphocytic leukemia; iNKT, invariant natural killer T cells; IL, interleukin; IFN, interferon; HV, healthy volunteer; $\alpha$-GalCer, $\alpha$-galactosylceramide; RT-qPCR, reverse transcription-quantitative polymerase chain reaction.

IFN- $\gamma$ (median $2^{-\Delta \mathrm{Cq}}$ : 5.50 vs. 2.70$)$ mRNAs after $\alpha$-GalCer stimulation (Fig. 6). After 24-h $\alpha$-GalCer stimulation the presence of IL-4 and IFN- $\gamma$ mRNAs was determined in iNKT cells isolated from patients with CLL as well as HVs. However, IL-4 or IFN- $\gamma$ mRNAs were identified at higher levels in iNKT cells from patients with CLL compared with iNKT cells of HVs $(\mathrm{P}<0.05)$. In the present study, IL-4 mRNA levels directly correlated with the percentage of IL-4-positive iNKT cells $(\mathrm{R}=0.481 ; \mathrm{P}<0.01)$. Similarly, IFN- $\gamma$ mRNA levels directly correlated with the percentage of iNKT cells with intracellular IFN- $\gamma$ expression $(\mathrm{R}=0.473 ; \mathrm{P}<0.01)$.

Membrane CDId expression on B cells and monocytes from patients with CLL and HVs. Our previous data (25) indicated that the median percentage of CD1d-positive B cells in patients with CLL was significantly lower than in HVs. Similarly, when the level of membrane CD1d expression determined by MFI on B cells was compared between patients with CLL and HVs, we identified a significant difference between the groups. In the present study, our previous results (25) that the percentage of B cells CD1d+ in CLL patients was significantly lower than in HVs were confirmed. Furthermore, in the current study, CD1d expression was detected on monocytes. Fig. 2 presents two representative types of monocytes with CD1d expression for patients with CLL (CLL1-CLL2), and two representative types of CD1d-positive monocytes for HVs (HV1-HV2). The percentage of monocytes with CD1d expression was significantly lower in patients with CLL in comparison with the HVs (median, 85.73\%; range, 65.78-99.15\% vs. median, 92.86\%; range, 88.55-99.89\%; $\mathrm{P}<0.05$ ). Similarly, the level of membrane CD1d expression determined by MFI on monocytes was reduced in patients with CLL (median 182.60 MFI in HVs; 161.40 MFI in the CLL group). However, this difference was not statistically significant. Furthermore, no significant association between the expression levels of IL-4 or IFN- $\gamma$ in iNKT cells and CD1d expression on leukemic B lymphocytes or monocytes from patients with CLL was identified.

Apoptosis. The ex vivo percentage of apoptotic B lymphocytes $\left(\Delta \Psi \mathrm{m}^{\text {low }} / \mathrm{CD} 19^{+}\right)$was significantly lower than the percentage of
$\Delta \Psi \mathrm{m}^{\text {low }} / \mathrm{CD} 19^{+}$lymphocytes in $24 \mathrm{~h}$ in vitro culture $(\mathrm{P}<0.05)$. However, there was no significant difference in the percentage of apoptotic CD19+ lymphocytes between the cultures with and without $\alpha$-GalCer (Table IV). No correlation between the percentage of iNKT ${ }^{+} \mathrm{IL}-4^{+}$or $\mathrm{iNKT}^{+} \mathrm{IFN}-\gamma^{+}$cells and the percentage of $\Delta \Psi \mathrm{m}^{\text {low }} / \mathrm{CD} 19^{+}$lymphocytes was noted. iNKT cells with various cytokine profiles did not affect B cell apoptosis. Additionally, no correlation was identified between the percentage of iNKT cells in PB from patients with CLL and the percentage of $\Delta \Psi \mathrm{m}^{\text {low }} / \mathrm{CD} 19^{+}$lymphocytes determined directly ex vivo.

\section{Discussion}

Deficiencies in cytokine production by the T-lymphocytes of patients with CLL have previously been noted in certain studies $(29,30)$, but few concentrated on the small but essential T cell subpopulation of iNKT (31). iNKT cells recognize lipid antigens, such as $\alpha \mathrm{GalCer}$, when presented in a complex with CD1d (32). To evaluate the functionality of iNKT lymphocytes, they were cultured in vitro and stimulated with the iNKT-specific ligand $\alpha$-GalCer. It is challenging to select suitable stimulation methods for the analysis of cytokine production, especially for rare cell populations (e.g., iNKT cells). In the present study, whole blood samples were stimulated in vitro. Analysis of cytokine synthesis in whole blood has been utilized in previous studies (33-35). Such a method may imitate the natural in vivo environment (34). It was identified that $\alpha$-GalCer stimulation induced a stronger intracellular cytokine response in patients with CLL, when compared with HVs. Following culture with $\alpha$-GalCer, iNKT cells exhibited upregulated expression of CD69, an early activation marker, indicating that the examined cells retained the ability to respond to stimulation. In patients with CLL, the percentage of iNKT ${ }^{+} \mathrm{IFN}-\gamma^{+}$cells, and of iNKT ${ }^{+} \mathrm{IL}_{-} 4^{+}$, was increased with the noticeable dominance of a iNKT subset with intracellular expression of IL-4, while in HVs, the percentage of iNKT cells with IL-4 and IFN- $\gamma$ expression was similar.

Changes in $\mathrm{T}$ cell cytokine secretion profile, associated with a Th2 shift, were described for advanced CLL cases (30). 
Hill et al (36) reported a reduction in IFN- $\gamma$ and IL-4 expression by $\mathrm{CD} 4^{+} \mathrm{T}$ cells from patients with CLL. However, little data concerning cytokine production by iNKT cells have previously been presented. Weinkove et al (31) analyzed the cytokine profile and the proliferative capacity of circulating iNKT cells from patients with CLL. These authors observed an increased tendency towards an iNKT CD4 ${ }^{+}$subset (characterized by a production of Th2 cytokines) and a reduced tendency towards an iNKT $\mathrm{CD}^{+}$subset, although the results were not statistically significant. A comparison of patients with CLL and HVs revealed a lack of functional differences in, and no difference in the numbers of, iNKT cells; the cytokine production and in vitro proliferation of iNKT were similar. In the study, the authors evaluated a population of iNKT cells obtained from patients primarily in the early stages of the disease (31). It was suggested that the analysis of iNKT cells from patients with advanced-stage CLL could provide more diverse results. In the present study, no significant differences were observed in the percentage of iNKT ${ }^{+} \mathrm{IL}_{-} 4^{+}$cells between the CLL risk groups. However, patients with CLL at Rai stage III-IV had a lower percentage of iNKT ${ }^{+} \mathrm{IFN}-\gamma^{+}$cells than those at Rai stage 0 . Concordant with our results, Tahir et al (21) identified a strong Th2 bias; $\alpha$-GalCer-stimulated iNKT cells from patients with prostate cancer predominantly produced IL-4, while the production of IFN- $\gamma$ was decreased. It must be emphasized that, in the present study, the iNKT $\mathrm{IFN}^{+} \gamma^{+}$: iNKT $\mathrm{IL}^{+} 4^{+}$ ratio was decreased in the CLL group as compared with in the HVs. An inverse correlation was identified between the iNKT TFN- $\gamma^{+}$: iNKT IL-4 ${ }^{+}$ratio and the WBC count, as well as the $\beta_{2}$-microglobulin levels. Furthermore, the ratio was lower in advanced-stages compared with the early stages of the disease, and was lower in ZAP-70-positive patients. Similarly, a tendency towards the reduction in the ratio of iNKT IFN $\gamma^{+}$to iNKT IL- $4^{+}$was observed in patients with CLL who also had del (11q22.3) and/or del (17p13.1). In a study of Dhodapkar et al (37), the loss of IFN- $\gamma$ production by freshly isolated iNKT cells in the course of progressive myeloma was observed. An increase in IL-4 production, in comparison to IFN- $\gamma$ expression, by iNKT cells was identified in mice following immunization with $\alpha$-GalCer $(38,39)$. Tahir et al (21) reported decreased IFN- $\gamma:$ IL-4 ratio in prostate cancer patients. IL-4 inhibits the programmed death of CLL $\mathrm{B}$ cells and prolongs the cell lifespan (40). This effect was not detected for the B cells obtained from healthy subjects (4). Smyth et al (41) suggested that IL-4 is not required for mediating $\alpha$-GalCer activity against cancer. The results suggest that the frequency of iNKT cells and the profile of cytokines expressed by iNKT cells does not affect B cell apoptosis in patients with CLL. The results obtained by Palmer et al (42) indicate that iNKT cells are dispensable in the development or accumulation of $\mathrm{CD}^{+} \mathrm{B}$ cells in mice prone to benign or leukemic CLL-like B cell expansion.

According to the literature, numerous studies have noted not only qualitative, but also quantitative changes concerning iNKT cells in the course of neoplastic diseases (21,43-47). The number of analyzed iNKT cells decreased in patients with solid tumors $(21,43,47)$ and hematological malignancies, in comparison with healthy subjects $(45,46,48)$. Fais et al (49) observed a significantly lower number of iNKT cells in patients with CLL compared with HVs. The results of the present study, and of our previous study (46), indicated a significantly lower percentage of iNKT cells in the PB of patients with CLL when compared with that of HVs. Certain prior studies have associated a reduced number of iNKT cells not with a tumor, but with a risk of tumor growth $(43,50)$. Conversely, Weinkove et al (31) suggested that the absolute number of circulating iNKT cells in patients with untreated CLL is normal, and the reduction occurred in a group of patients undergoing chemotherapy. The data obtained in the current study are concordant with those recently reported by Weinkove et al (31), who determined there was no significant association between the iNKT cell frequency and the clinical disease stage or expression of adverse prognostic markers (i.e., ZAP-70).

In the present study, flow cytometry and RT-qPCR were used to detect the levels of IL-4 and IFN- $\gamma$ mRNA in iNKT cells. The level of transcription for IL- 4 and IFN- $\gamma$ was higher in leukemic B cells compared with HVs. Similarly, the percentage of iNKT cells expressing these molecules was higher in patients with CLL. However, the methods used in the present study were not able to indicate whether iNKT cells with IL-4 and IFN- $\gamma$ expression could also secrete IL-4 and IFN- $\gamma$. Nevertheless, the pattern of IL- 4 and IFN- $\gamma$ expression in the cytoplasm of iNKT cells together with the expression of IL-4 and IFN- $\gamma$ mRNA may suggest that iNKT cells are able to produce these cytokines. Further study is required in order to determine whether a change in the pattern of released cytokines may have an important role in the pathogenesis of CLL. It must be noted that no significant association was identified between the percentage of iNKT cells with intracellular IL-4 or IFN- $\gamma$ expression and the TTT. Furthermore, no statistically significant difference was observed in the iNKT IFN- $\gamma^{+}$: iNKT ${ }^{+} \mathrm{IL}-4^{+}$ratio between the patients requiring therapy and the patients without treatment.

CD1d expression is crucial for the presentation of glycolipids to iNKT cells (31). It was previously demonstrated that there is lower CD1d molecule expression in the B cells of patients with CLL, as compared with HVs (25). Similarly, Weinkove et al (31) identified that leukemic B cells express CD1d at lower levels. The results of the current study are consistent with those of Weinkove et al (31), who reported reduced CD1d expression on the monocytes of patients with CLL. Nevertheless, the role of CD1d in antitumor immunity is not well understood. It has been reported that iNKT cells fail to develop in $\mathrm{CD}_{1} \mathrm{~d}^{--}$mice (51). Wang et al (52) identified that resting iNKT cells that had not been exposed to APC with CD1d expression did not contain detectable levels of IFN- $\gamma$ mRNA. Fais et al (49) reported that CD1d on leukemic B cells was able to present $\alpha$-GalCer to NKT cells, as revealed by cytokine production, cytotoxicity and proliferation assays. In the present study, no association between the expression levels of IL-4 or IFN- $\gamma$ in iNKT cells and CD1d molecule expression on leukemic B lymphocytes or monocytes of patients with CLL was identified.

Numerous issues concerning the development and progression of CLL are still unclear. Over the years, numerous abnormalities concerning leukemic B lymphocytes and non-leukemic cells of the immune system that occur during the course of CLL have been characterized (53). The functional dysfunction of NKT-like cells in terms of cytokine 
production have previously been demonstrated (54). However, there are currently few publications concerning the cytokine expression profiles of iNKT cells obtained from patients with CLL $(31,49)$. By producing a variety of cytokines, the iNKT lymphocytes modify the microenvironment and, therefore, may influence tumor growth $(21,55,56)$. As an important regulator of the Th1/Th2 balance $(21,56)$, iNKT cells may have a significant role in the pathogenesis of CLL. An attempt was made to evaluate the ratio of iNKT ${ }^{+} \mathrm{IFN}-\gamma^{+}$: iNKT ${ }^{+} \mathrm{IL}^{+}$ in patients with CLL. It was expected that its decrease may result in the promotion of leukemic B lymphocyte survival. However, in the present study iNKT cells with multiple cytokines profiles did not affect B cell apoptosis. Although iNKT cells are considered to enhance the antitumor response $(57,58)$ in certain tumors, such as CLL, the cells may gain specific immunosuppressive properties $(25,54)$. However, further studies are required. In the present study, $\mathrm{CD} 4^{+} \mathrm{CD} 25^{+} \mathrm{Foxp} 3^{+}$ regulatory $\mathrm{T}$ cells $\left(\mathrm{T}_{\text {regs }}\right)$ were not analyzed. Nevertheless, an inverse correlation was identified between the percentages of iNKT cells and $\mathrm{CD} 4{ }^{+} \mathrm{CD} 25^{\text {high }} \mathrm{T}$ cells (data not presented). $\mathrm{T}_{\text {regs }}$ can suppress the proliferation, cytokine secretion and cytotoxic activity of NKT cells (59). Monitoring the number and function of iNKT cells may be important for assessing immunological dysfunction in patients with CLL. However, currently it cannot unequivocally be said that monitoring the percentage of iNKT cells or their function can provide useful information concerning the activity or progression of the disease. In the present study, only two cytokines were analyzed. They were chosen since they represent cytokines typical for Th1- and Th2-type lymphocy tes with a well-known antagonizing action. Further analysis of other cytokines produced by iNKT cells, including IL-17 and TGF- $\beta$, may be important for understanding the pathogenesis of CLL.

\section{Acknowledgements}

The present study was supported in part by a research grant (grant no. N N402 439139) from the State Funds for Scientific Research National Science Centre (NCN) and by a grant from the Medical University of Lublin (grant no. DS 458).

\section{References}

1. Joyce JA: Therapeutic targeting of the tumor microenvironment. Cancer Cell 7: 513-520, 2005.

2. Burger JA and Gribben JG: The microenvironment in chronic lymphocytic leukemia (CLL) and other B cell malignancies: Insight into disease biology and new targeted therapies. Semin Cancer Biol 24: 71-81, 2014.

3. Tinhofer I, Rubenzer G, Holler C, Hofstaetter E, Stoecher M, Egle A, Steurer M and Greil R: Expression levels of CD38 in $\mathrm{T}$ cells predict course of disease in male patients with $\mathrm{B}$-chronic lymphocytic leukemia. Blood 108: 2950-2956, 2006.

4. Mainou-Fowler T and Prentice AG: Modulation of apoptosis with cytokines in B-cell chronic lymphocytic leukaemia. Leuk Lymphoma 21: 369-377, 1996.

5. Terabe M, Swann J, Ambrosino E, Sinha P, Takaku S, Hayakawa Y, Godfrey DI, Ostrand-Rosenberg S, Smyth MJ and Berzofsky JA: A nonclassical non-Valpha14Jalpha18 CD1d-restricted (type II) NKT cell is sufficient for down-regulation of tumor immunosurveillance. J Exp Med 202: 1627-1633, 2005.

6. Gapin L: Development of invariant natural killer T cells. Curr Opin Immunol 39: 68-74, 2016.

7. Dellabona P, Abrignani S and Casorati G: iNKT-cell help to B cells: A cooperative job between innate and adaptive immune responses. Eur J Immunol 44: 2230-2237, 2014.
8. Exley M, Porcelli S, Furman M, Garcia J and Balk S: CD161 (NKR-P1A) costimulation of CD1d-dependent activation of human $\mathrm{T}$ cells expressing invariant $\mathrm{V}$ alpha $24 \mathrm{~J}$ alpha $\mathrm{Q} \mathrm{T}$ cell receptor alpha chains. J Exp Med 188: 867-876, 1998.

9. Seino K and Taniguchi M: Functionally distinct NKT cell subsets and subtypes. J Exp Med 202: 1623-1626, 2005.

10. Godfrey DI, MacDonald HR, Kronenberg M, Smyth MJ and Van Kaer L: NKT cells: What's in a name? Nat Rev Immunol 4: 231-237, 2004.

11. Kawano T, Cui J, Koezuka Y, Toura I, Kaneko Y, Motoki K, Ueno H, Nakagawa R, Sato H, Kondo E, et al: CD1d-restricted and TCR-mediated activation of valpha14 NKT cells by glycosylceramides. Science 278: 1626-1629, 1997.

12. Spada FM, Koezuka Y and Porcelli SA: CD1d-restricted recognition of synthetic glycolipid antigens by human natural killer T cells. J Exp Med 188: 1529-1534, 1998.

13. HayakawaY,GodfreyDIandSmythMJ:Alpha-galactosylceramide: Potential immunomodulatory activity and future application. Curr Med Chem 11: 241-252, 2004.

14. Matsuda JL, Naidenko OV, Gapin L, Nakayama T, Taniguchi M, Wang CR, Koezuka Y and Kronenberg M: Tracking the response of natural killer T cells to a glycolipid antigen using CD1d tetramers. J Exp Med 192: 741-754, 2000.

15. Matsuda JL, Mallevaey T, Scott-Browne J and Gapin L: CD1d-restricted iNKT cells, the 'Swiss-Army knife' of the immune system. Curr Opin Immunol 20: 358-368, 2008.

16. Gumperz JE, Miyake S, Yamamura T and Brenner MB: Functionally distinct subsets of CD1d-restricted natural killer $\mathrm{T}$ cells revealed by CD1d tetramer staining. J Exp Med 195: 625-636, 2002.

17. Brennan PJ, Brigl $\mathrm{M}$ and Brenner MB: Invariant natural killer T cells: An innate activation scheme linked to diverse effector functions. Nat Rev Immunol 13: 101-117, 2013.

18. Godfrey DI and Kronenberg M: Going both ways: Immune regulation via CD1d-dependent NKT cells. J Clin Inves 114: 1379-1388, 2004.

19. Fujii S, Shimizu K, Smith C, Bonifaz L and Steinman RM: Activation of natural killer $\mathrm{T}$ cells by alpha-galactosylceramide rapidly induces the full maturation of dendritic cells in vivo and thereby acts as an adjuvant for combined CD4 and CD8 T cell immunity to a coadministered protein. J Exp Med 198: 267-279, 2003.

20. Smyth MJ and Godfrey DI: NKT cells and tumor immunity-a double-edged sword. Nat Immunol 1: 459-460, 2000.

21. Tahir SM, Cheng O, Shaulov A, Koezuka Y, Bubley GJ, Wilson SB, Balk SP and Exley MA: Loss of IFN-gamma production by invariant NK T cells in advanced cancer. J Immunol 167: 4046-4050, 2001.

22. Hallek M, Cheson BD, Catovsky D, Caligaris-Cappio F, Dighiero G, Döhner H, Hillmen P, Keating MJ, Montserrat E, Rai KR, et al: Guidelines for the diagnosis and treatment of chronic lymphocytic leukemia: A report from the international workshop on chronic lymphocytic leukemia updating the national cancer institute-working group 1996 guidelines. Blood 111: 5446-5456, 2008.

23. Rai KR, Sawitsky A, Cronkite EP, Chanana AD, Levy RN and Pasternack BS: Clinical staging of chronic lymphocytic leukemia. Blood 46: 219-234, 1975.

24. Livak KJ and Schmittgen TD: Analysis of relative gene expression data using real-time quantitative PCR and the 2(-Delta Delta C(T)) method. Methods 25: 402-408, 2001.

25. Bojarska-Junak A, Hus I, Chocholska S, Tomczak W, Woś J, Czubak P, Putowski L and Roliński J: CD1d expression is higher in chronic lymphocytic leukemia patients with unfavorable prognosis. Leuk Res 38: 435-442, 2014.

26. Bojarska-Junak A, Hus I, Chocholska S, Wasik-Szczepanek E, Sieklucka M, Dmoszyńska A and Roliński J: BAFF and APRIL expression in B-cell chronic lymphocytic leukemia: Correlation with biological and clinical features. Leuk Res 33: 1319-1327, 2009.

27. Sieklucka M, Pozarowski P, Bojarska-Junak A, Hus I, Dmoszynska A and Rolinski J: Apoptosis in B-CLL: The relationship between higher ex vivo spontaneous apoptosis before treatment in III-IV Rai stage patients and poor outcome. Oncol Rep 19: 1611-1620, 2008.

28. Bojarska-Junak A, Hus I, Olszewska-Bożek K, Chocholska S, Wąsik-Szczepanek E, Tomczak W, Miłczak J, Dmoszyńska A and Roliński J: Analysis of ex vivo apoptosis of B and T cells from peripheral blood and bone marrow of patients with chronic lymphocytic leukemia. Acta Haematol Pol 43: 336-341, 2012. 
29. Christopoulos P, Pfeifer D, Bartholomé K, Follo M, Timmer J, Fisch P and Veelken H: Definition and characterization of the systemic T-cell dysregulation in untreated indolent B-cell lymphoma and very early CLL. Blood 117: 3836-3846, 2011

30. Rossmann ED, Lewin N, Jeddi-Tehrani M, Osterborg A and Mellstedt H: Intracellular T cell cytokines in patients with B cell chronic lymphocytic leukaemia (B-CLL). Eur J Haematol 68: 299-306, 2002.

31. Weinkove R, Brooks CR, Carter JM, Hermans IF and Ronchese F: Functional invariant natural killer T-cell and CD1d axis in chronic lymphocytic leukemia: Implications for immunotherapy. Haematologica 98: 376-384, 2013.

32. Borg NA, Wun KS, Kjer-Nielsen L, Wilce MC, Pellicci DG, Koh R, Besra GS, Bharadwaj M, Godfrey DI, McCluskey J and Rossjohn J: CDld-lipid-antigen recognition by the semi-invariant NKT T-cell receptor. Nature 448: 44-49, 2007.

33. Fernandez CS, Cameron G, Godfrey DI and Kent SJ: Ex-vivo $\alpha$-galactosylceramide activation of NKT cells in humans and macaques. J Immunol Methods 382: 150-159, 2012.

34. Ai W, Li H, Song N, Li L and Chen H: Optimal method to stimulate cytokine production and its use in immunotoxicity assessment. Int J Environ Res Public Health 10: 3834-3842, 2013.

35. Liu Z, Yuan X, Luo Y, He Y, Jiang Y, Chen ZK and Sun E: Evaluating the effects of immunosuppressants on human immunity using cytokine profiles of whole blood. Cytokine 45: 141-147, 2009.

36. Hill SJ, Peters SH, Ayliffe MJ, Merceica J and Bansal AS: Reduced IL-4 and interferon-gamma (IFN-gamma) expression by CD4 T cells in patients with chronic lymphocytic leukaemia. Clin Exp Immunol 117: 8-117, 1999.

37. Dhodapkar MV, Geller MD, Chang DH, Shimizu K, Fujii S Dhodapkar KM and Krasovsky J: A reversible defect in natural killer T cell function characterizes the progression of premalignant to malignantmultiple myeloma. J Exp Med 197: 1667-1676, 2003.

38. Singh N, Hong S, Scherer DC, Serizawa I, Burdin N, Kronenberg M, Koezuka Y and Van Kaer L: Cutting edge: Activation of NK T cells by CD1d and alpha-galactosylceramide directs conventional $\mathrm{T}$ cells to the acquisition of a Th2 phenotype. J Immunol 163: 2373-2377, 1999.

39. Burdin N, Brossay L and Kronenberg M: Immunization with alpha-galactosylceramide polarizes CD1-reactive NK T cells towards Th2 cytokine synthesis. Eur J Immunol 29: 2014-2025, 1999.

40. Dancescu M, Rubio-Trujillo M, Biron G, Bron D, Delespesse G and Sarfati M: Interleukin 4 protects chronic lymphocytic leukemic B cells from death by apoptosis and upregulates Bcl-2 expression. J Exp Med 176: 1319-1326, 1992.

41. Smyth MJ, Crowe NY, Pellicci DG, Kyparissoudis K, Kelly JM, Takeda K, Yagita H and Godfrey DI: Sequential production of interferon-gamma by NK1.1(+) T cells and natural killer cells is essential for the antimetastatic effect of alpha-galactosylceramide. Blood 99: 1259-1266, 2002.

42. Palmer VL, Nganga VK, Rothermund ME, Perry GA and Swanson PC: Cd1d regulates B cell development but not B cell accumulation and IL10 production in mice with pathologic CD5(+) B cell expansion. BMC Immunol 16: 66, 2015

43. Molling JW, Kölgen W, van der Vliet HJ, Boomsma MF, Kruizenga H, Smorenburg CH, Molenkamp BG, Langendijk JA, Leemans CR, von Blomberg BM, et al: Peripheral blood IFN-gamma-secreting Valpha24+Vbeta11+ NKT cell numbers are decreased in cancer patients independent of tumor type or tumor load. Int J Cancer 116: 87-93, 2005.
44. Giaccone G, Punt CJ, Ando Y, Ruijter R, Nishi N, Peters M, von Blomberg BM, Scheper RJ, van der Vliet HJ, van den Eertwegh AJ, et al: A phase I study of the natural killer T-cell ligand alpha-galactosylceramide (KRN7000) in patients with solid tumors. Clin Cancer Res 8: 3702-3709, 2002.

45. Yoneda K, Morii T, Nieda M, Tsukaguchi N, Amano I, Tanaka H, Yagi H, Narita N and Kimura H: The peripheral blood Valpha24+ NKT cell numbers decrease in patients with haematopoietic malignancy. Leuk Res 29: 147-152, 2005.

46. Hus I, Bojarska-Junak A, Gonet-Sebastianka J, Glazer M, Drab E, Woś J and Roliński J: iNKT cell percentage is decreased in patients with chronic lymphocytic leukemia and correlates inversely with the clinical stage and negative prognostic factors. Centr Eur J Immunol 36: 79-84, 2011.

47. Singh AK, Shukla NK and Das SN: Altered invariant natural killer $\mathrm{T}$ cell subsets and its functions in patients with oral squamous cell carcinoma. Scand J Immunol 78: 468-477, 2013.

48. Fujii S, Shimizu K, Klimek V, Geller MD, Nimer SD and Dhodapkar MV: Severe and selective deficiency of interferon-gamma-producing invariant natural killer $\mathrm{T}$ cells in patients with myelodysplastic syndromes. Br J Haematol 122: 617-622, 2003

49. Fais F, Morabito F, Stelitano C, Callea V, Zanardi S, Scudeletti M, Varese P, Ciccone E and Grossi CE: CD1d is expressed on B-chronic lymphocytic leukemia cells and mediates alpha-galactosylceramide presentation to natural killer T lymphocytes. Int J Cancer 109: 402-411, 2004.

50. Fujii S, Shimizu K, Okamoto Y, Kunii N, Nakayama T, Motohashi S and Taniguchi M: NKT cells as an ideal anti-tumor immunotherapeutic. Front Immunol 4: 409, 2013.

51. Mendiratta SK, Martin WD, Hong S, Boesteanu A, Joyce S and Van Kaer L: CD1d1 mutant mice are deficient in natural T cells that promptly produce IL-4. Immunity 6: 469-477, 1997.

52. Wang X, Bishop KA, Hegde S, Rodenkirch LA, Pike JW and Gumperz JE: Human invariant natural killer T cells acquire transient innate responsiveness via histone $\mathrm{H} 4$ acetylation induced by weak TCR stimulation. J Exp Med 209: 987-1000, 2012.

53. Lanasa MC: Novel insights into the biology of CLL. Hematology Am Soc Hematol Educ Program 2010: 70-76, 2010.

54. Bojarska-Junak A, Hus I, Sieklucka M, Wasik-Szczepanek E, Mazurkiewicz T, Polak P, Dmoszynska A and Rolinski J: Natural killer-like T CD3+/CD16+CD56+ cells in chronic lymphocytic leukemia: Intracellular cytokine expression and relationship with clinical outcome. Oncol Rep 24: 803-810, 2010.

55. Robertson FC, Berzofsky JA and Terabe M: NKT cell networks in the regulation of tumor immunity. Front Immunol 5: 543, 2014.

56. Wang Y, Hu X, Guo C, Zhang Q, Peng J, Zhang J, Li L, Zhang T and Xu C: Polarization of natural killer T cells towards an NKT2 subpopulation occurs after stimulation with alpha-galactosylceramide and rhG-CSF in aplastic anemia. Acta Haematol 119: 178-186, 2008.

57. Mattarollo SR and Smyth MJ: NKT cell adjuvants in therapeutic vaccines against hematological cancers. Oncoimmunology 2: e22615, 2013

58. McEwen-Smith RM, Salio M and Cerundolo V: The regulatory role of invariant NKT cells in tumor immunity. Cancer Immunol Res 3: 425-435, 2015

59. La Cava A, Van Kaer L and Fu-Dong-Shi: CD4+CD25+ Tregs and NKT cells: Regulators regulating regulators. Trends Immunol 27: 322-327, 2006.

This work is licensed under a Creative Commons Attribution-NonCommercial-NoDerivatives 4.0 International (CC BY-NC-ND 4.0) License. 